\title{
eHealth: je gezondheid in een 'app' op je mobiele telefoon
}

\section{ELLEN DINGEMANS}

Op allerlei gebieden in de zorg vinden enorme technologische ontwikkelingen plaats. Ook daar waar het gaat om communicatie en informatieverzameling. Afspraken met de arts maak je via een website en de applicaties, of 'apps', om je gezondheid bij te houden op je mobiele telefoon of tablet schieten als paddenstoelen uit de grond. In hoeverre maken wij gebruik van deze technologische vooruitgang? Uit de 'eHealth monitor' van het $\mathrm{Ne}$ derlands instituut voor onderzoek van de gezondheidszorg NIVEL blijkt dat we steeds vaker gebruik maken van een eHealth toepassing om onze gezondheid te monitoren. Van de mensen jonger dan 50 jaar zien we dat in 20I4 I I procent minimaal eens per jaar een eHealth toepassing gebruikte en dit is gestegen tot bijna 20 procent in 2016 . Het zal niet verbazen dat het percentage lager ligt onder ouderen. Maar ook onder ouderen wordt het zelf monitoren van gezondheid via eHealth populairder. Het aandeel gebruikers ouder dan 65 is tussen 2014 en 2016 meer dan verdubbeld van vijf naar $\mathrm{I} 2$ procent.

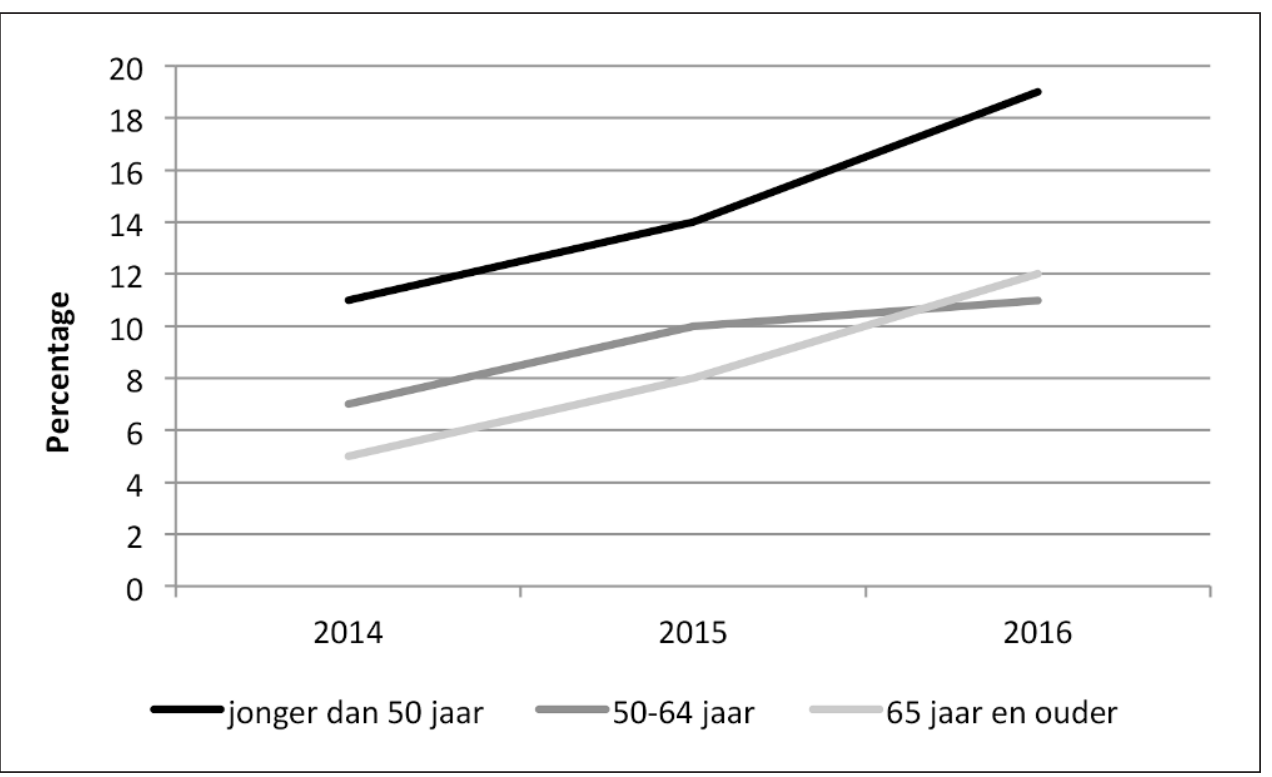

